\title{
Free-living flatworms under the knife: past and present
}

\author{
Bernhard Egger • Robert Gschwentner • \\ Reinhard Rieger
}

Received: 28 August 2006 / Accepted: 24 October 2006 / Published online: 5 December 2006

(C) Springer-Verlag 2006

\begin{abstract}
Traditionally, regeneration research has been closely tied to flatworm research, as flatworms (Plathelminthes) were among the first animals where the phenomenon of regeneration was discovered. Since then, the main focus of flatworm regeneration research was on triclads, for which various phenomena were observed and a number of theories developed. However, free-living flatworms encompass a number of other taxa where regeneration was found to be possible. This review aims to display and to compare regeneration in all major free-living flatworm taxa, with special focus on a new player in the field of regeneration, Macrostomum lignano (Macrostomorpha). Findings on the regeneration capacity of this organism provide clues for links between regeneration and (post-)embryonic development, starvation, and asexual reproduction. The role of the nervous system and especially the brain for regeneration is discussed, and similarities as well as particularities in regeneration among free-living flatworms are pointed out.
\end{abstract}

Keywords Platyhelminthes Planarian · Acoela .

Rhabditophora $\cdot$ Catenulida

\section{Introduction}

Regeneration research in flatworms has a long standing history, but was focussed on triclads since its beginning in 1774, when Pallas (Pallas 1774) described the regeneration of the triclads Dendrocoelum lacteum and Bdellocephala

Communicated by R.J. Sommer

B. Egger $(\bowtie) \cdot$ R. Gschwentner $\cdot$ R. Rieger

Ultrastructural Research and Evolutionary Biology,

University of Innsbruck,

Innsbruck, Austria

e-mail: bernhard.egger@uibk.ac.at punctata (from Brøndsted 1969). Since then, a vast amount of studies about regeneration in flatworms has appeared (for recent reviews, see Agata and Watanabe 1999; Sánchez Alvarado 2000, 2003, 2004, 2006; Saló and Baguñà 2002; Newmark and Sánchez Alvarado 2002; Agata 2003; Agata et al. 2003; Reddien and Sánchez Alvarado 2004; Reuter and Kreshchenko 2004; Sánchez Alvarado and Kang 2005; Saló 2006), but many of the old questions and many of the most intriguing phenomena that have been discovered cannot be explained today. Why can some animals regenerate, while others cannot? How is the duplication of heads or tails (heteromorphoses) possible in adult organisms? What conditions are sufficient and what are necessary for successful regeneration? Is regeneration a side-product of asexual reproduction, or the other way round? Is regeneration recapitulating pathways used in embryonic and postembryonic development? How are stem cells controlled and directed in regeneration? Are stem cells in adult flatworms totipotent, and can they be likened to embryonic blastomeres? This review provides a brief synopsis on what is known about the regeneration capacity in free-living flatworms, and addresses open questions about regeneration, with special emphasis on an emerging model organism, Macrostomum lignano (Egger et al. 2006a,b).

A comparison of the regeneration capacity of the macrostomorph flatworm $M$. lignano with other free-living flatworms necessarily involves a look at their phylogenetic relationship. The Macrostomorpha belong to the largest taxon Rhabditophora, which also encompasses the Polycladida, Lecithoepitheliata, Prolecithophora, Proseriata, Bothrioplanida, Tricladida, Rhabdocoela, and the parasitic Neodermata (Ehlers 1985; Rieger 1996; Tyler et al. 2006). Macrostomorpha are considered to be the most basal taxon within the Rhabditophora due to a simple pharynx, entolecithal eggs, and the lack of vitellaria (Ehlers 1985). Referring to their small size (millimeter range), macro- 
stomorphans are members of the "microturbellarians", a nonsystematic denomination. Polyclads and triclads are the only taxa belonging to the "macroturbellaria", with forms generally in the centimeter range. Triclads, as more derived rhabditophorans, have vitellaria, a rather complicated embryonic development (e.g., Cardona et al. 2005) and an often very pronounced regeneration capacity (see Brøndsted 1969).

The status of the acoels

While many molecular (e.g., Baguñà and Riutort 2004a,b) and also some morphological studies (e.g., Reuter et al. 2001, summed up in Egger and Ishida 2005) have placed the acoels outside the Plathelminthes, a number of characteristics (apomorphies) speak in favor of acoels being flatworms (Ehlers 1985), most notably the stem cell system and the special mode of epidermal replacement (Smith et al. 1986; Tyler and Hooge 2004). In this review, acoels and nemertodermatids are considered members of the Plathelminthes.

What is a planarian?

In flatworm regeneration research, other groups than triclads are often neglected and can easily be overlooked. This may in part be due to an ambiguous use of the term "planarian", which is most often referring merely to triclads (more specifically, to paludicolans, e.g., Agata 2003; Reddien and Sánchez Alvarado 2004), but is also commonly used as a synonym for all free-living flatworms (e.g., Baguñà 1998; Saló and Baguñà 2002) or even used interchangeably for free-living flatworms and triclads alike (e.g., Newmark and Sánchez Alvarado 2001). The term "freshwater planarian", while somewhat more specific, is still ambiguous, as a number of nontriclad flatworms, e.g., Stenostomum and Microstomum, are freshwater dwellers as well. In publications dealing with several flatworm taxa, it is often unclear what the term planarian signifies.

It seems therefore desirable to agree on using less ambiguous denominations in scientific contexts, such as unequivocal scientific names, and to get rid of the term planarian.

\section{Overview of regeneration capacity in free-living flatworm groups}

All major free-living flatworm taxa with their tentative general regeneration capacities are given in Fig. 1. Asexually reproducing forms are only known for acoels, catenulids, macrostomorphans, and triclads. Within freeliving flatworms, either catenulids (Ehlers 1985) or acoelomorphs (acoels and nemertodermatids, Rieger 1996) are considered as the basal-most taxon. All other flatworms are

\section{Regeneration capacity}

\begin{tabular}{|c|c|c|}
\hline unknown & & Nemertodermatida \\
\hline excellent & $\begin{array}{l}\text { asexual } \\
\text { forms }\end{array}$ & Acoela \\
\hline excellent & $\begin{array}{c}\text { asexual } \\
\text { forms }\end{array}$ & Catenulida \\
\hline excellent & $\begin{array}{l}\text { asexual } \\
\text { forms }\end{array}$ & Macrostomorpha \\
\hline good & & Polycladida \\
\hline poor & & Lecithoepitheliata \\
\hline good & & Prolecithophora \\
\hline good & & Proseriata \\
\hline excellent & $\begin{array}{c}\text { asexual } \\
\text { forms }\end{array}$ & Tricladida \\
\hline good & & Bothrioplanida \\
\hline poor & & Rhabdocoela \\
\hline
\end{tabular}

Fig. 1 The regeneration capacity of the major free-living flatworm taxa. In all groups with asexual reproduction, species with a pronounced regeneration capacity can be found (green shades). Not all species in the listed taxa are necessarily showing the same regeneration capacity; only a broad classification of regeneration capacities is given. The major taxa were compiled after Ehlers (1985), Rieger (1996), and Tyler et al. (2006)

encompassed by the rhabditophorans, with macrostomorphans and polyclads at the base (Ehlers 1985; Rieger 1996).

Catenulida

The regeneration capacity of two catenulid genera, namely, Stenostomum and Catenula, has been extensively investigated. Probably linked with asexual reproduction (paratomy), excellent regeneration capacity has been reported after artificial amputation (Ritter and Congdon 1900; Child 1903a,b; Ruhl 1927a; van Cleave 1929; and Palmberg 1990 for Stenostomum; Moraczewski 1977 for Catenula). Regeneration from the so-called organ primordia was found to be possible for all organ systems.

Acoela

Based on experiments mainly with Polychoerus caudatus (Stevens and Boring 1905; Child 1907; Keil 1929) and Paramecynostomum diversicolor (Peebles 1913), Hyman notes that acoels "have limited powers of regeneration" (Hyman 1951, p 182). The studied species were not able to regenerate ganglia (brain) or the statocyst. Later studies with Amphiscolops langerhansi (Steinböck 1954, 1955, 1963a,b) and Hofstenia giselae (Steinböck 1966, 1967) illustrated a substantial regeneration capacity in these acoels, where $H$. giselae was found to even regenerate the 
statocyst after amputation (Steinböck 1966). Several species can regenerate their eyes (Hanson 1967 for $A$. langerhansi and Pseudohaplogonaria sutcliffei, Yamasu 1991 for Praesagittifera naikaiensis, and Åkesson et al. 2001 for Convolutriloba longifissura).

Acoels are now known to show all main modes of asexual reproduction, that is architomy (e.g., C. longifissura, Åkesson et al. 2001), paratomy (e.g., Paratomella unichaeta, Ax and Schulz 1959), and budding (e.g., C. retrogemma, Hendelberg and Åkesson 1988). Architomy is characterized by fission before formation of new organs, paratomy by formation of new organs before fission. Budding refers to a special case of paratomy, where the axis of the new piece is not corresponding to the axis of the old piece-in C. retrogemma, the axis of the buds is tilted by $180^{\circ}$ in relation to the main animal (Hendelberg and Åkesson 1988, 1991).

\section{Nemertodermatida}

No account of regeneration potential or asexual reproduction has been given for animals from this taxon.

\section{Macrostomorpha}

As already observed in catenulids and acoels, the regeneration capacity of macrostomorphans is closely associated with the mode of reproduction. Thus, in the asexually reproducing taxa Microstomum lineare and Alaurina (paratomy), the regeneration capacity is most pronounced and all organs can be regenerated (von Graff 1908; Ruhl 1927a; Palmberg 1986, 1990, 1991). Regeneration research with the exclusive sexually reproducing genus Macrostomum started with Ruhl (1927a), who found that Macrostomum tuba cannot regenerate the head (brain, eyes, and pharynx) and requires at least a quarter of the gut in the anterior piece to be able to regenerate posterior parts, including copulatory organs. More recently, Ladurner et al. (1997) noted that in Macrostomum hystricinum marinum and Macrostomum pusillum the anterior part can fully regenerate the posterior part, while the posterior part cannot regenerate the anterior part. Similar findings were reported for M. lignano: cut in midbody, only the anterior part was found to regenerate the missing part (Rieger et al. 1999). Salvenmoser et al. (2001) described the regeneration of the musculature in $M$. lignano after the removal of the posterior end. Using the same species, Egger et al. (2006a,b) characterized the regeneration capacity at various cutting levels. Anterior regeneration is possible if the animals are cut in front of the brain; posterior regeneration can be successful from cutting levels starting with the posterior end of the pharynx. A distinct regeneration blastema occurs in $M$. lignano, but not in M. lineare, where organ primordia are formed without conspicuous accumulation of neoblasts at the wound site (Palmberg 1986).
Polycladida

The best-studied polyclad genus regarding regeneration is Leptoplana. Leptoplana alcynoe (now Letoplana alcinoi) and Leptoplana velutinus, as well as Thysanozoon brocchi and Cryptocelis alba, were shown to regenerate posterior parts by Monti (1900a). Using Leptoplana atomata, Schultz (1901, 1902) observed the regeneration of the posterior part, including gonads and copulatory organs, whereas head and pharynx were not regenerated. Similar results were obtained with Leptoplana tremellaris and L. alcinoi, although the pharynx was found to regenerate here (Child 1904a-c, 1905a; von Levetzow 1939). L. tremellaris can regenerate both anterior and posterior parts if only about half the brain is removed by transversal amputation. At amputation levels posterior of the brain, no complete anterior regeneration is possible (Child 1904a-c). Notoplana humilis shows a comparable regeneration capacity (Ishida 1998). Besides more posterior parts, T. brocchi is also able to regenerate the main tentacles, gut, and pharynx (Monti 1900a; von Levetzow 1939). Studying regeneration in Leptoplana saxicola, Pucelis litoricola, and Planocera californica, Olmsted (1922a) reports that these species follow the "polyclad rule for regeneration", that is, regeneration of all amputated parts (including eyes) is possible if the brain remains intact. Several studies were dedicated to find out whether polyclads can regenerate the brain (Morgan 1905 for Leptoplana littoralis and von Levetzow 1939 for T. brocchi), and how the behavior changes after excision of the brain (Morgan 1905; Olmsted 1922b; von Levetzow 1939; Koopowitz et al. 1975, 1976) or after severance of the main lateral nerve cords (Olmsted 1922b; Koopowitz et al. 1975, 1976). Severed nerve cords and brain halves can fuse and resume their functions (Olmsted 1922b; Faisst et al. 1980), but the brain is not regenerated. Full anterior regeneration, including the brain, after complete removal of the brain was only observed in Cestoplana, provided the amputation level is a short distance behind the brain (Child 1905b). All mentioned species, except T. brocchi, are members of the taxon Acotylea (Tyler et al. 2006). From what is known, both Cotylea and Acotylea seem to share a comparable regeneration capacity.

Lecithoepitheliata

Only scarce reports about regeneration are available for this neoophoran taxon. For Prorhynchus stagnalis, Ruhl (1927a) remarks that no regeneration capacity whatsoever could be detected at anterior, posterior, and midbody cutting levels. The posterior pieces survived for 30 days. When cutting Geocentrophora baltica a short distance behind the pharynx, no regeneration could be observed (Steinböck 1927). All pieces died at the latest after 17 days. 
A closer examination of the regeneration capacity of Geocentrophora sphyrocephala revealed that these animals can approximately rebuild the mouth opening anteriorly in 3-5 weeks but cannot regenerate the brain. Both parts die after 40 days if the animals are cut just behind the pharynx. Cut in midbody or more posteriorly, the anterior part can regenerate the tail with adhesive organs in $2-3$ weeks, although the animals were never observed to reach the original body length. The posterior part dies without regeneration after 1 day (Hagleithner 1946).

\section{Prolecithophora}

According to Pechlaner (1957), Plagiostomum lemani is reported to have a low regeneration capacity (Keller 1894), while Plagiostomum girardi can regenerate all amputated parts (Monti 1900b).

\section{Proseriata}

von Graff (1882) describes amputation experiments with Monocelis fusca, where posterior pieces resumed movement after 3-5 days. In M. fusca, Monocelis lineata and other monocelidids (Coelogynopora, Archilopsis), and also in otoplanids (Itaspiella, Bothriomolus), Giesa (1966) observed posterior regeneration of parts containing the brain in 3-4 days. Even pieces amputated just behind the brain can regenerate. The brain does not regenerate, though. In Otomesostoma auditivum, Pechlaner (1957) found promising regeneration potential, severely limited by a short life span of 9-10 months and low living temperatures (about $4^{\circ} \mathrm{C}$ ). Gut, part of the gonads, and sensory organs can regenerate. First signs of pharynx, eye, and brain regeneration were observed after 9-15 weeks, but the animals died before regeneration was complete. The statocyst was not regenerated.

\section{Bothrioplanida}

While no extensive regeneration studies have been undertaken, Sekera (1911) found that Bothrioplana semperi is able to regenerate the pharynx posteriorly.

\section{Tricladida}

Dalyell (1814) noted that Planaria nigra (today: Polycelis nigra) could "almost be called immortal under the edge of the knife" (in Brøndsted 1969). However, not all triclad species are equally powerful regarding regeneration. Ŝivickis (1930) distinguished five groups of triclads according to their ability to regenerate a head. This classification was subsequently refined into eight types by Teshirogi et al. (1977). For the Phagocata velata type, the
Dugesia dorotocephala type, the Polycelis auriculata type, and the Dendrocoelopsis lactea type 2 (Sapporo population), regeneration of a head is possible from any part of the body, but with varying probability of success. Animals of the Dendrocoelopsis lactea type 1 (Kuroishi population) fail to regenerate a head from tail pieces up to the male gonopore. The Dendrocoelopsis ezensis type and the Dendrocoelum lacteum type 1 are very similar in that they are generally only able to regenerate a head if amputated anterior to the pharynx, whereas the Bdelloura type (e.g., Bdelloura candida) completely lacks the ability to regenerate a head. While a vast amount of literature on regeneration in triclads is available, recent publications are not so much concerned with studying the regeneration capacities of different triclads, but more with unraveling cellular and molecular mechanisms of regeneration in only a few model triclads, such as Dugesia japonica and Schmidtea mediterranea.

Rhabdocoela

The typhloplanoid flatworm Mesostoma ehrenbergi cannot regenerate any organs, only approximately restore the original shape posteriorly (Steinmann and Bresslau 1913). Regeneration experiments with Mesostoma productum, Mesostoma lingua, and Mesostoma punctatum revealed that anterior regeneration of parts in front of the brain is possible, although often done imperfectly. The tail can regenerate; the more posterior the cut is made, the better is the regeneration. Brain and pharynx cannot be regenerated (Fulinski 1922). In Phaenocora unipunctata and Phaenocora megalops (also typhloplanoids), no regeneration capacity was found (Fulinski 1922). For the the dalyelliid Dalyellia millportiana and the kalyptorhynch Gyratrix hermaphroditus, Ruhl (1927a) remarks curtly that all animals died within 1 day after amputation and no regeneration being observable. Dalyellia viridis and Typhloplana viridata survive the amputation of the caudal-most part of the tail, but show no signs of regeneration, not even of the adhesive organs. In Rhynchomesostoma rostratum, another typhloplanoid, the amputated tail tip is regenerated, or at least a tail-like shape is restored (Hein 1928).

\section{Comparison of the regeneration capacity between free-living flatworm taxa}

While the experimental evidence for some groups is still patchy, we find three main types of regeneration capacity in free-living flatworms. Some taxa cannot regenerate at all, such as most rhabdocoels and some lecithoepitheliates. On the other end of the scope are species that can regenerate all organs, such as the acoel Convolutriloba, the catenulid Stenostomum, the macrostomorphan Microstomum, the 
polyclad Cestoplana, and many triclads. Most taxa however lie in between these extremes, lacking the ability to regenerate brain, eyes, pharynx, or statocyst (many acoels), but are able to regenerate gonads, copulatory organs, sucker, duo-gland adhesive systems, gut, and the anteriormost part in front of the brain.

The regeneration capacity of $M$. lignano can be likened most closely to triclads of the Bdelloura group, which cannot regenerate a head (brain or eyes). Most polyclads, although often able to regenerate a pharynx, are also roughly comparable to Macrostomum regarding their regeneration capacity. Members of other diverse taxa like lecithoepitheliates and rhabdocoels are bearing resemblance with regeneration in Macrostomum as well. Such similarities can be found crossing the boundaries of the major flatworm taxa, making the regeneration capacity a feature of no immediate phylogenetic value. Close relatives like Microstomum and Alaurina (both macrostomids) surpass Macrostomum's regeneration capacity by far.

\section{Asexual reproduction and regeneration}

Not surprisingly, the ability to regenerate is often linked to asexual reproduction (Fig. 1, Brøndsted 1969; Sánchez Alvarado 2000). In taxa lacking asexual reproduction, the regeneration capacity is generally less pronounced than in taxa with asexual reproduction, where regeneration is necessarily involved (Brøndsted 1969; Reuter and Kreshchenko 2004). As described in the section "Acoela", in architomy, regeneration events follow fission, while in paratomy and budding, the term "pregeneration" seems to be more accurate, as organs are duplicated in the presence of the old organs in the new animal (zooid) before fission occurs. The notable difference between regeneration and pregeneration is the presence of a brain in the latter, which is regarded as a decisive organ for regeneration in many species (Henley 1974; Kreshchenko et al. 2001). It is interesting to note that the catenulid Stenostomum leucops, reproducing asexually by paratomy, often fails to regenerate a head if amputated artificially (van Cleave 1929). This finding hints at an actual difference between paratomy and architomy regarding the influence on regeneration capacity.

Asexual reproduction in flatworms occurs in more basal taxa (Acoela, Catenulida, and Macrostomorpha) as well as in more derived taxa (Tricladida and Neodermata). Triclads, like acoels, show paratomy (Dugesia fissipara and Dugesia paramensis, Hyman 1951) as well as architomy (e.g., Dugesia tahitiensis, Peter et al. 2001). Just like regeneration capacity, asexual reproduction is too dispersed among diverse taxa to provide insight into phylogenetic relationships.
Why can some flatworm species regenerate while others cannot?

If a profound regeneration capacity is a plesiomorphic feature, there might have been a selection pressure against regeneration during evolution (Goss 1991; in Sánchez Alvarado 2000). Why would such a useful feature be reduced or abolished? Because regeneration is dangerous, as a plethora of evidence of double-headed or doubletailed flatworms testify. Such aberrant forms are easily produced in species that can regenerate (see section "Heteromorphoses"), but are not known from flatworms lacking regeneration capabilities. Other than as a side effect of asexual reproduction, the ability to regenerate is seemingly not useful enough to outweigh the inherent dangers. What are the chances that a predator spares a tail fragment that can regenerate to a complete animal in a couple of days if left alone? What are the chances that a disease only affects a part of the animal, but spares the rest to readily regenerate the damaged organs? A totipotent stem cell system out of control might be too high a risk for comparably little reward. This could be the reason why regeneration capabilities decreased in species that no longer propagate through asexual reproduction.

In this light, it seems more likely that in evolutionary terms, asexual reproduction is a primitive and not a derived feature (Rieger 1986; Gremigni 1992; Reuter and Kreshchenko 2004), and that regeneration capability results from asexual reproduction as an added bonus. Regeneration can be seen as a form of asexual reproduction, only triggered by different stimuli.

What is the decisive factor that determines the regeneration capacity of a species? Citing regeneration experiments with Dendrocoelum and Bdellocephala, Brøndsted (1969) comes to the conclusion "that the posterior part of the body in these two species simply lacks the potential to respond to head inducing substances". This may also hold true for $M$. lignano, considering that in transversal amputations a head was never regenerated, but in longitudinal incisions a second head - in the presence of the original head - could be formed (Fig. 2c,d, Egger et al. 2006a,b). This experiment suggests that the ability to induce head formation, although present in adult $M$. lignano, is restricted to the head region only. Serotonin and possibly other substances related to the brain or nervous system might be key factors deciding on the regeneration capacity of flatworms.

It is interesting to note that double-headed specimens of $M$. lignano can sometimes be observed in untreated culture dishes. These aberrant forms might rather be the result of twin embryos (Fig. 2a) that have grown together during embryonic development, than adults that were accidentally incised longitudinally (Sekera 1911; Steinmann and Bresslau 1913; Seilern-Aspang 1958). 
Fig. 2 Heteromorphoses resulting from embryogenesis and regeneration. a Twin embryo of M. lignano, 8-cell stage. The two embryos are not separated by a dividing wall. In some cases, such embryos may grow to siamese twins. Diameter of individual embryos is about $150 \mu \mathrm{m}$. b Different animal than a found in culture dishes. The juvenile animals are connected at the level of the pharynx, possibly the result of two embryos growing together. c Adult M. lignano, 1 week after longitudinal incision (arrowhead). Only a small indentation is visible. d Same specimen as in c 29 days after longitudinal incision. A second head with brain, a single eye, and pharynx has emerged. Scale bars are $100 \mu \mathrm{m}$. c, d Same scale bar
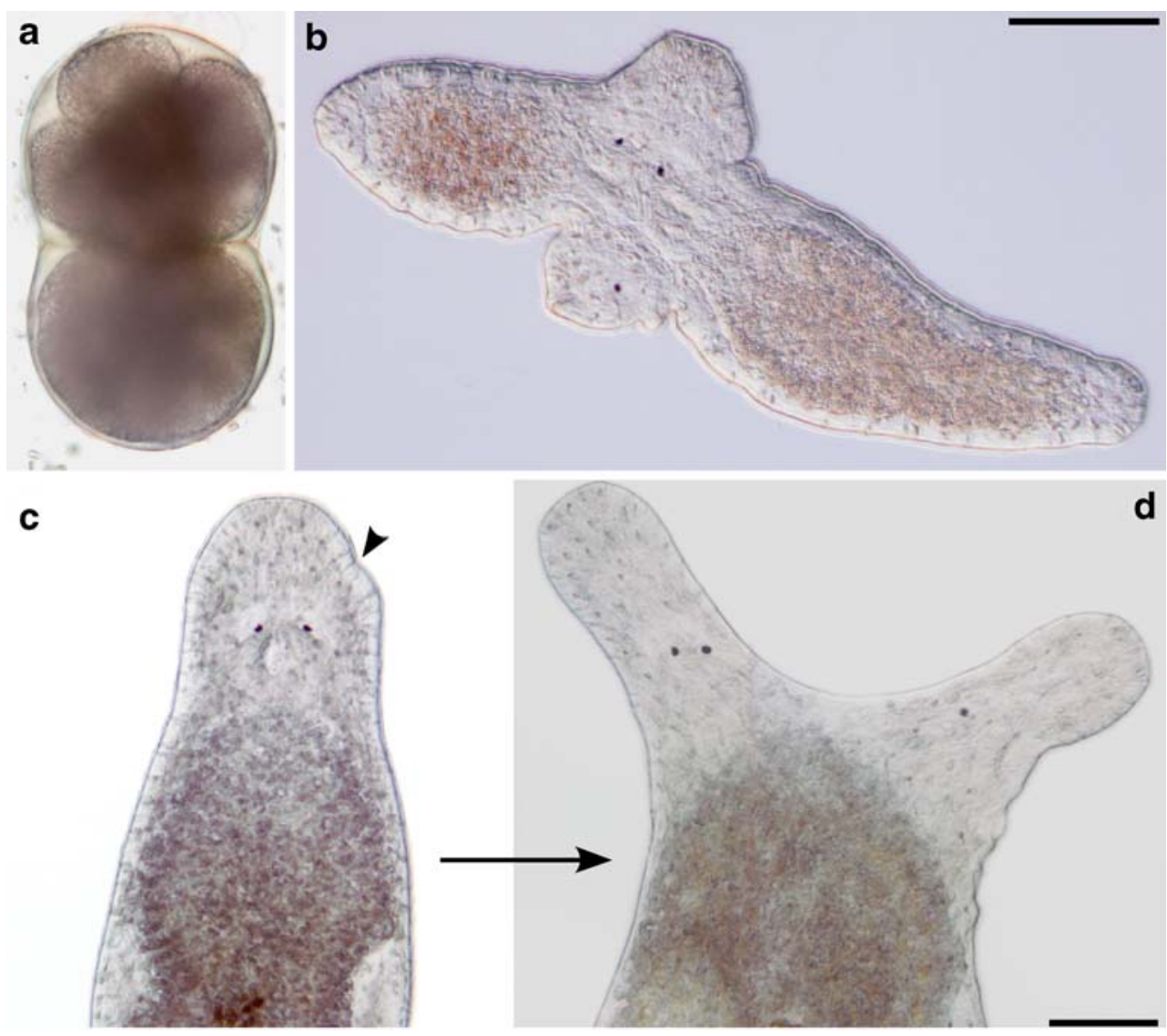

\section{Ovaries restricting regeneration?}

The possible evolutionary origin and function of regeneration aside, what genetical, physiological, developmental, or environmental factors are responsible to determine to what extent an organism can regenerate? Even close relatives may differ vastly in regeneration capacity (e.g., Microstomum-Macrostomum), and also the same species in different developmental stages. Stenostomum alternates seasonally between asexual and sexual reproduction (protandric hermaphroditism). Asexual and male specimens of Stenostomum grande can regenerate all organs, but lose the ability to regenerate a head after the appearance of ovaries (van Cleave 1929). While the presence of ovaries and the loss of regeneration capacity might be coincidental, it appears possible that in $S$. grande ovaries are producing substances that inhibit regeneration. Could sexualization be directly affecting a general decrease of regeneration potential? At present, the molecular nature of such an inhibitory substance remains unclear. Vasa-related genes are expressed strongly both in gonads and in the early blastema in D. japonica and in M. lignano (Shibata et al. 1999; Pfister and Ladurner 2005), making an inhibitory function of vasa during regeneration improbable, at least in these two species. Also, contrary to the findings in Stenostomum, several triclads are known to regenerate all organs in the presence of gonads (e.g., S. mediterranea, Sánchez Alvarado 2003). Two possibilities may explain differences in the regeneration capacity in the presence of ovaries: either the ovaries in Stenostomum are producing a unique inhibitory substance that is not synthesized in Schmidtea, or Schmidtea is able to counteract the effects of such an inhibitory agent.

\section{Regeneration in juveniles}

If gonads, specifically ovaries, are indeed hindering regeneration in some species, then sexually immature juveniles could possibly be more potent regenerates than adults. In the rhabdocoel Mesostoma, young animals (the author does not specify their age) are reported to regenerate better than adults (Fulinski 1922). Contrastingly, in the acoel species $H$. giselae, no regeneration even of large juveniles (2.5 mm long) takes place (Steinböck 1967).

In most cases, however, juveniles regenerate as well (or bad) as adults. An explanation is that gene expression for the building of gonads is already occurring in immature animals, thus diminishing possible differences in the regeneration capacity between juveniles and adults. Regeneration in juvenile triclads has been studied in B. punctata by Brøndsted, who found that animals recently hatched 
from cocoons were able to regenerate the head at the same rate as mature adults (Brøndsted 1942, 1969). Pechlaner (1957) studied the regeneration of freshly hatched animals, juveniles and mature adults in the proseriate $O$. auditivum. He did not observe significant differences in the regeneration capacity between these age groups. Neither juvenile nor adult dalyellids were found to regenerate (Hein 1928). In the lecithoepitheliate $G$. sphyrocephala, the regeneration capacity of juveniles corresponds to that of adults (Hagleithner 1946). The results for M. lignano support these findings and show that even very young animals (1 day after hatching) are capable of regeneration, indicating that the neoblast stem cell system is already present and functional as found in adults. Accordingly, BrdU labeling of 1-day-old hatchlings revealed a similar pattern of Sphase cell distribution as in adults, with the majority of labeled cells along the sides of the animal, and no labeled cells in the rostrum. Just like adults, juveniles were not able to regenerate a head (Egger et al. 2006a,b).

\section{Similarities between postembryonic development and regeneration}

However similar, regeneration has some characteristics not shared with postembryonic development. Unlike postembryonic development, regeneration in flatworms is triggered by a disruptive event like fission or amputation (but not by chemical destruction of tissue, burning, or high voltage; see Brøndsted 1969). As in other flatworms, in M. lignano, the wound is soon closed after amputation by contraction of the ring musculature minimizing the wound surface, and by flattening of the surrounding epidermal cells (Salvenmoser et al. 2001). In the next days, undifferentiated cells (neoblasts) accumulate at the wound site, forming a distinct blastema, covered by new and old epidermal cells. Subsequently, differentiation of microorgans and organs becomes prevalent within the blastema, superseding the blastema proper (Egger et al. 2005, 2006a,b). Epidermal cells are not undergoing mitoses, as new epidermal cells and blastema cells are derived from neoblasts located in the mesodermal space. Different to triclads, neoblasts are proliferating also within the blastema, not only at the blastema border (Egger et al. 2005). While wound closure and blastema formation are regeneration-specific events, similarities between regeneration and postembryonic development become prevalent starting with differentiation in the (former) blastema. In extreme cases, where only a small piece remains for regeneration (e.g., in pharynx-level regenerates, Egger et al. 2006a,b), resemblance with postembryonic development is particularly striking (Fig. 3). The remaining organs in these regenerates undergo extensive morphallactic changes to accommodate to the new body proportions (Fig. $3 n-0$ in Egger et al. 2006a).

One week after amputation, pharynx-level regenerates of M. lignano are confronted with similar challenges as freshly hatched juveniles: both have to build gonads and the male and female genital organs, grow a full set of duo-gland adhesive glands, and increase their size by five or six times (Figs. 3a,b, and 4). It seems plausible, that after wound healing and restoration of the basic functionality of the gut, pharynx-level regenerates are making use of similar or same developmental pathways that are used in hatchlings (Fig. 4) (cooption, Sánchez Alvarado 2000). This view is supported by the ability of hatchlings and juveniles to regenerate just like adults, and by the similarity of the stem cell system in hatchlings, juveniles, and adults (Ladurner et al. 2000; Egger et al. 2006a,b). Vasa gene expression is similar in hatchlings and in gonad-recovering regenerates as well (Pfister and Ladurner 2005). Also, the time needed for developing to a full-grown adult in M. lignano is about the same for hatchlings (Morris et al. 2004) and 1-week-old pharynx-level regenerates, that is about 2 weeks (Fig. 3 and Egger et al. 2006a,b). In the proseriate M. fusca, the regeneration of small anterior pieces also goes through stages similar to postembryonic development (Giesa 1966), which is observed in triclads as well (Baguñà 1998). Starved adults, reducing their size and breaking down the gonads (Nimeth et al. 2004), are also likely recapitulating their postembryonic development while growing back to full size (Fig. 4). Not only is regeneration akin to postembryonic development, amputated animals can even be rejuvenated by regeneration (Fig. 4 and Haranghy and Balázs 1964 for triclads, Egger et al. 2006a,b for $M$. lignano). While untreated animals were found to live for about 10 months in culture conditions, they were outlived by animals amputated 45 times over a period of 20 months, effectively doubling their life span so far (Egger et al. 2006a,b; Egger, unpublished observations). At the time of writing, many of these repeatedly amputated animals are still alive.

A fountain-of-youth effect through starvation was shown to occur in triclads (Haranghy and Balázs 1964), but was not yet proven for M. lignano (Fig. 4).

\section{Embryonic development and regeneration}

Early embryogenesis is vastly different between diverse free-living flatworm taxa (for recent publications, see Jondelius 2004 for nemertodermatids; Ramachandra et al. 2002 for acoels; Morris et al. 2004 for macrostomorphans, Younossi-Hartenstein and Hartenstein 2000 for polyclads, Cardona et al. 2005 for triclads, and Younossi-Hartenstein and Hartenstein 2001 for rhabdocoels). Even comparably 
a
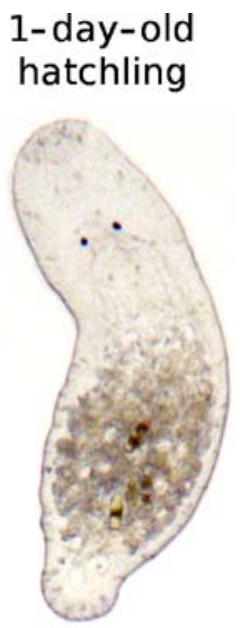

c

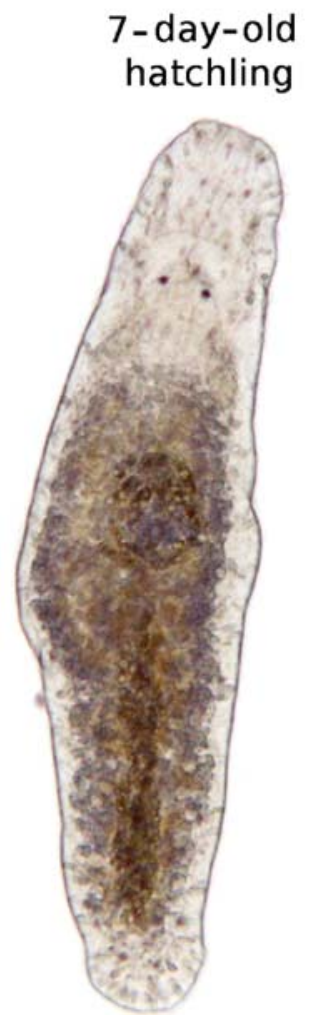

b
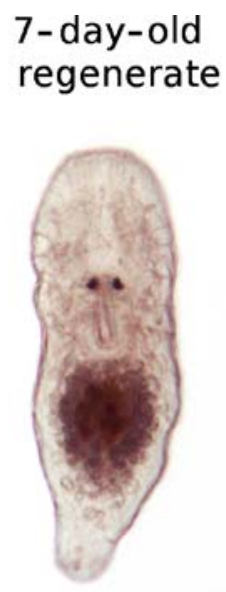

14-day-old regenerate

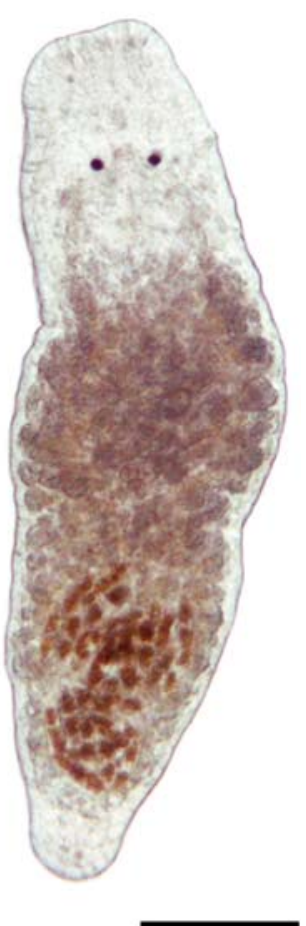

Fig. 3 Comparison of $M$. lignano hatchlings with posterior regenerates amputated at the pharynx level. $\mathbf{b}$ and $\mathbf{d}$ are depicting the same individual. a Hatchling up to $24 \mathrm{~h}$ old. b Pharynx level regenerate 7 days after amputation. c 7-day-old hatchling. d Pharynx level regenerate 14 days after amputation. Scale bar for all subpanels is $100 \mu \mathrm{m}$

close relatives show significant differences in their early embryonic development. Lacking vitellaria and therefore producing entolecithal eggs, Macrostomorpha and Polycladida are the only archoophoran Rhabditophora, placing them at the basal-most positions in this largest flatworm taxon (Ehlers 1985; Rieger 1996). Nonetheless, their early embryonic development starts to deviate after about the third cleavage (Fig. 5). If developmental pathways from the embryonic development are reused in regeneration, it is most likely from the formation of organ primordia and later stages (Fig. 4). Cardona et al. (2005) point out the similarities between embryogenesis and early regeneration in triclads concerning the building of a provisional epidermis and the development of muscles and nerves, suggesting that not only postembryonic, but also embryonic developmental pathways are utilized during regeneration, a viewpoint shared with Vannini (1966). A comparison of gene expression patterns between regenerates (see Reddien et al. 2005 for triclads), late embryos and hatchlings seem to be a worthwhile task.

Early blastomere ablation in polyclads has revealed a determinative development as in other spiralians (Boyer 1986), the fate of blastomeres depending on micromeremacromere interaction (Boyer 1989). Polyclads do not have an invariant cell lineage, however (Boyer 1992). Polyclad embryos can be obtained devoid of an eggshell (Fig. 5a) and still develop normally in a culture dish treated with antibiotics. Regeneration experiments with polyclad embryos may thus be relatively easy to carry out and could provide additional clues about the requirements for regeneration in flatworm embryos. Also, the regeneration capacity of polyclad larvae, as compared to hatchlings of directly developing polyclads, would be interesting to know. A connection between regulation in early embryonic development and regeneration capacity does not seem to exist. This notion is supported by regeneration experiments with embryos of the triclad $P$. nigra. Regeneration does not take place before organ systems, such as the nervous system, reach a certain degree of differentiation in the embryo, so that stage five embryos are unable to regenerate, while stage six embryos with a more differentiated nervous system readily regenerate lost parts (Le Moigne 1966). This author held that the nervous system plays a critical role in the formation of a blastema during regeneration.

\section{Nervous system and role of the brain for regeneration}

The nervous system, especially the brain, has long been considered to play a key role in regeneration (Kreshchenko et al. 2001). In many free-living flatworms, posterior parts can be regenerated, while the brain cannot. In anterior regenerates of $M$. lignano missing the brain, a blastema-like structure was observed, which was unable to give rise to all missing organs. The more posterior the animals were amputated, the less pronounced was this abortive anterior blastema (Egger et al. 2006a,b). In Macrostomum, are the brain and the nerve cell clusters associated with the pharynx (Fig. 6) required to release factors needed for the regeneration of brain, eyes, and pharynx? The study of 


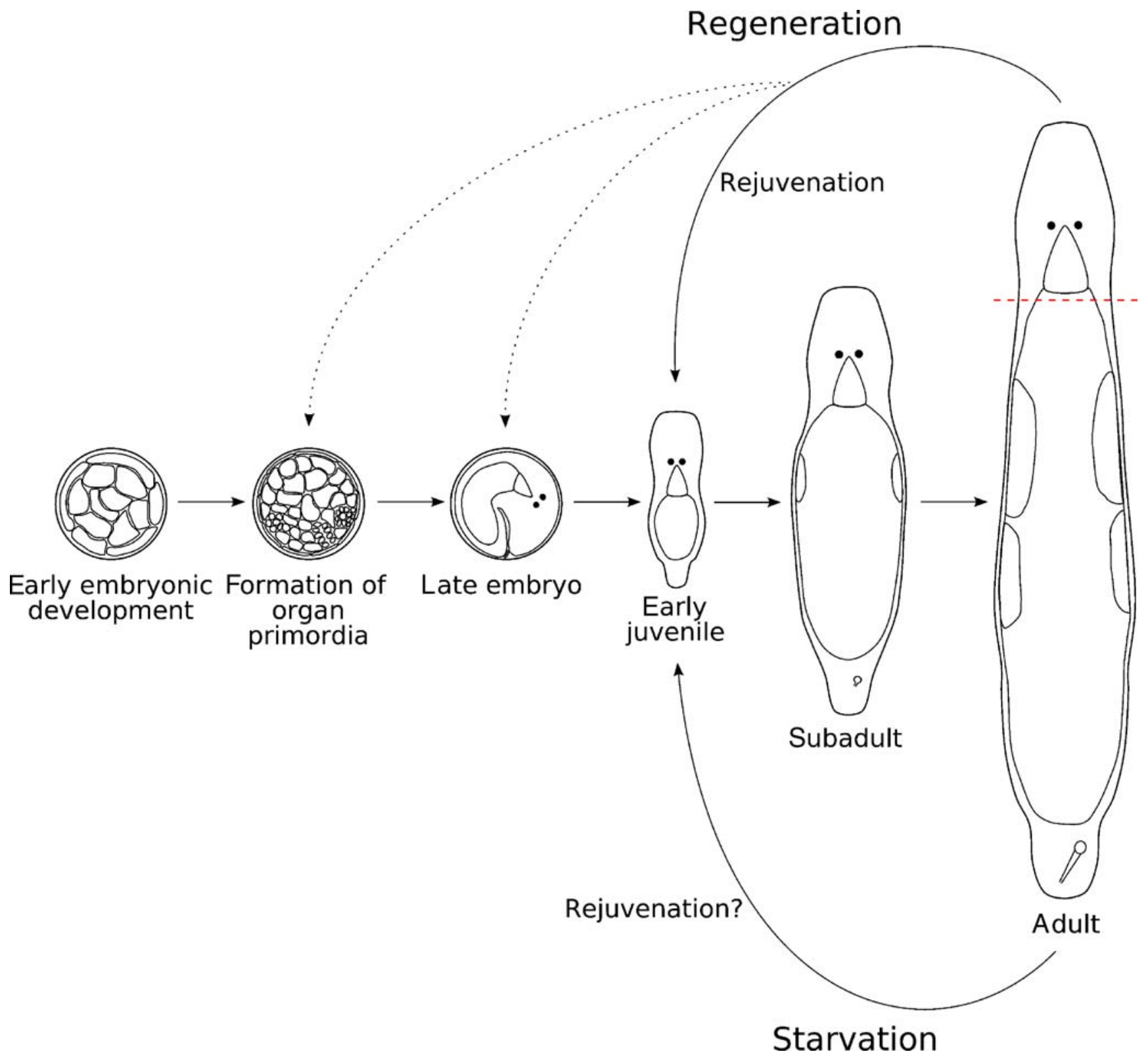

Fig. 4 Similarities between (post-)embryonic development, regeneration, and starvation considering as example M. lignano. Successive developmental stages from left to right, from embryonic to postembryonic development (formation of gonads and genital organs) until adulthood. Regeneration If an adult animal is amputated just posterior of the pharynx, the anterior piece will pass stages similar to early juveniles and subadults before regeneration to a normal adult is completed. The same animal can be amputated repeatedly, each time seemingly repeating parts of its postembryonic development. Repeated regeneration was also shown to have a rejuvenation effect. A connection between the formation of organ

gene expression in head-amputated regenerates of the triclads $D$. japonica and $S$. mediterranea revealed necessary genes for regeneration of the brain (Cebrià et al. 2002a; Koinuma et al. 2003; Cebrià and Newmark 2005). Also, with nou-darake a factor was identified that restricts brain tissue to the head region of $D$. japonica. If nou-darake is primordia during embryonic development and the organ differentiation in regenerating animals is possible, but has not been shown yet for $M$. lignano. Some developmental pathways are likely shared between late embryos and regenerates as well, e.g., the initial building of microorgans like the duo-gland adhesive systems. Both in embryos and posterior regenerates, these organs are built from scratch. Starvation Animals starved for 30 days or longer break down their gonads and genital organs shrink, but can recover and regain sexual prowess after feeding. Starvation leading to an extended life span was shown for triclads and is also likely to occur in M. lignano

interrupted by RNA interference, brains appear in all body regions (Cebrià et al. 2002b). In species that are not able to regenerate a brain, nou-darake or a similar factor might be expressed not only in the brain region but also throughout the body, thus preventing the formation of a new brain even if the old brain was lost. 
Fig. 5 Early embryonic development of two basal rhabditophorans. a The 12-cell stage of the polyclad Pseudostylochus intermedius. Egg without eggshell. b 12-cell stage of the macrostomorphan M. lignano. Different to the clear spiral cleavage of polyclads, $M$. lignano forms the so-called hull cells after the third cleavage to enclose the rest of the embryo. The diameter of the embryos is about $150 \mu \mathrm{m}$
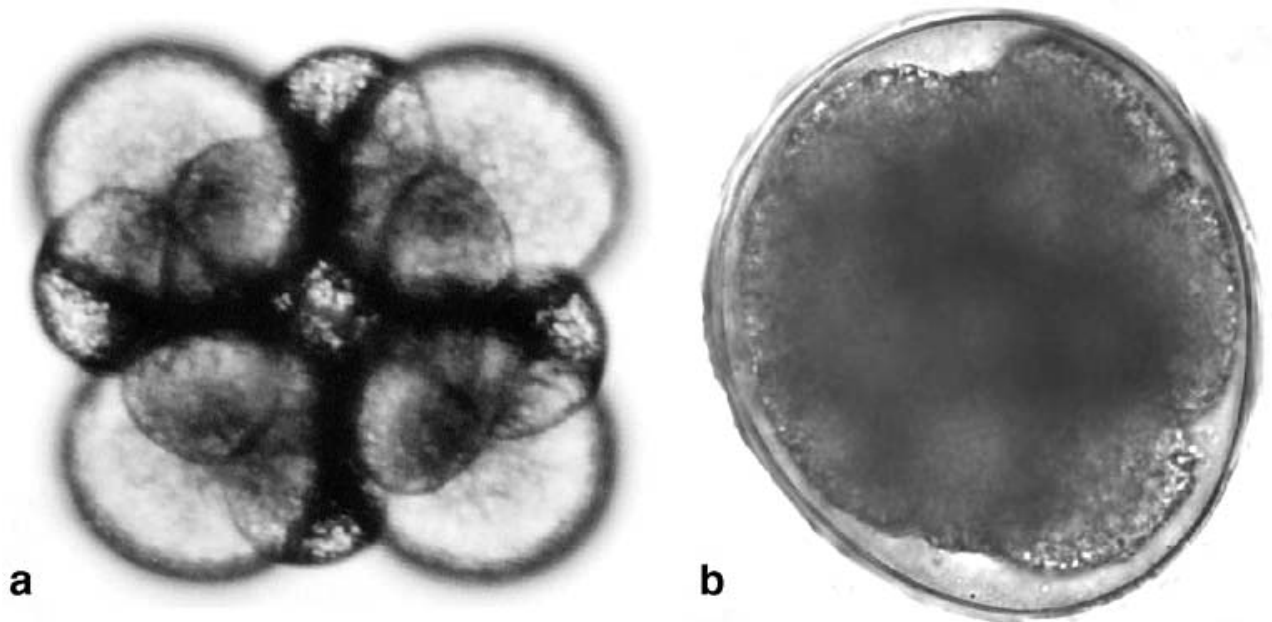

In M. hystricinum marinum and M. pusillum, large clusters of serotonergic cells have been found besides the posterior part of the pharynx (Ladurner et al. 1997). These results were corroborated for $M$. lignano by staining of the serotonergic and the GYIRFamidergic nervous system (Fig. 6). Amputees cut in the middle of the pharynx lose this cluster of nerve cells, as well as a large part of the pharynx, which is known to be a critical structure for regeneration in some triclads (Brøndsted 1969) and polyclads (Ishida 1998). Ladurner et al. (1997) held that the distribution of serotonergic nerve cells is correlated with the regeneration capacity. In species where serotonergic neurons are restricted to the head area, the posterior part of the animals cannot regenerate the head. In the asexually reproducing species $M$. lineare and $S$. leucops, serotonergic nerve cells are found over the whole length of the main nerve cords.

The inability of $M$. lignano to regenerate eyes after transversal amputation or oblique amputation between the eyes, is possibly linked with a severe brain damage caused by these amputations, and the loss of strongly immunoreactive cells in front of the eyes (Fig. 6c). In two cases of longitudinal incisions, lost eyes were regenerated or supernumerary eyes were built-but in these cases, the brain was only slightly injured. In a series of experiments, Lender (1950, 1951a-c) and Wolff and Lender (1950a,b) stress the importance of the head ganglia for the regeneration of eyes in $P$. nigra. If the brain was repeatedly excised or X-irradiated, no regeneration of eyes took place: an intact brain was obviously required to induce eye regeneration. These results were corroborated for Dugesia (now Schmidtea) lugubris by Török (1958). However, L. littoralis, L. saxicola, and $P$. litoricola can regenerate eyes even if the brain was excised (Morgan 1905; Olmsted 1922a).

Vannini (1965) observed in S. lugubris and P. nigra that the testes do not regenerate in the absence of a brain. Ghirardelli (1965) found that if a two-headed Dugesia was decapitated on one side, the testes on the same side degenerated. Contrastingly, the gonads in $M$. lignano are viable for an extended period of time after decapitation or oblique amputation between the eyes, and are only reduced if the pharynx is lost as well, causing malnourishment and starvation (Egger et al. 2006a,b). This may be an indication that the building of the gonads is not under the primary control of the brain in $M$. lignano, just like the tail plate can be built without the presence of a head. The regeneration of a tail in headless regenerates is possible in M. lignano as well as in triclads of the Dendrocoelum group (Brøndsted 1939, 1969), in the polyclads L. littoralis, L. saxicola, and P. litoricola (Morgan 1905; Olmsted 1922a), and also in the rhabdocoel Mesostoma (Fulinski 1922). Therefore, the head in all of these organisms is not required to control the regeneration of the tail. In Cestoplana and T. brocchi, the pharynx can regenerate in the absence of the brain (Child 1905c; von Levetzow 1939); in Cestoplana often a secondary pharynx is built in the presence of the old pharynx (Child 1905c). Also, the regulation of tissue breakdown (e.g., gonads) and body size reduction during starvation is possible in decapitated pieces, so the brain is not responsible for this regulation as well. Headless $M$. lignano with intact pharynx are able to feed, in accordance with the polyclads Notoplana acticola and Planocera gilchristi (Koopowitz et al. 1976). These animals are able to identify and devour food in the absence of a brain, while Enchiridium punctatum, a polyclad possessing a tubular instead of a plicate pharynx, cannot feed without the brain (Koopowitz et al. 1976). Similarly, some triclads, also equipped with a tubular pharynx, are not able to feed if the brain was amputated (Hyman 1951). Brainless M. ehrenbergi cannot feed but can move normally (Steinmann and Bresslau 1913), whereas brainless Phaenocera is reported to behave similarly to normal animals (Fulinski 1922). $G$. sphyrocephala, different to $M$. lignano, cannot adhere to the substrate after decerebration (Hagleithner 1946).

The main function of the brain in M. lignano is probably to be found in directed motion (e.g., light avoidance, 
Fig. 6 Immunocytochemical stainings of the nervous system of $M$. lignano. Confocal images. a GYIRFamidergic immunoreactivity. Clusters of immunoreactive cells are found lateral to the pharynx and in front of the eyes. b, c Serotonergic immunoreactivity in the head region. b Full stack of confocal images. Note the stained cell clusters lateral to the pharynx and in front of the eyes. c Subset of image stack in b. In this focal plane, stained cells anterior to the eyes become apparent. Arrowheads denote the level of the eyes
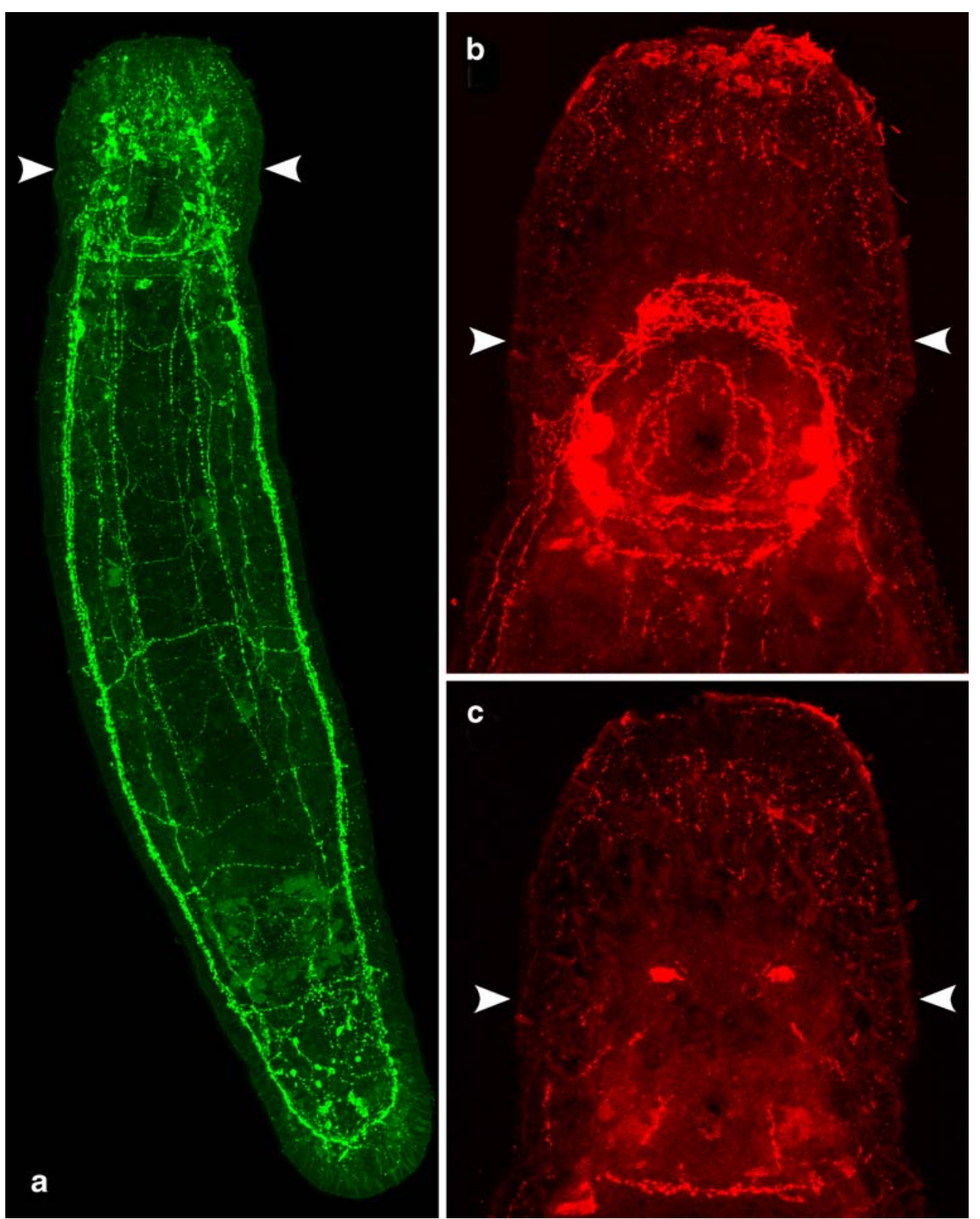

predator avoidance; see also Koopowitz et al. 1976 and literature therein), satiation reflex (Koopowitz et al. 1976), mating behavior (Scharer et al. 2004), and chemical analyzation of the medium.

\section{The totipotency of neoblasts}

Pharynx-level regenerates of $M$. lignano have shown that the regeneration of gonads is possible after removal of all gonadal tissue. The viability of the regenerated gonads has been demonstrated by breeding experiments with fully regenerated animals. Besides the gonads, also the gut and the copulatory organs have been rebuilt de novo in pharynx-level regenerates (Egger et al. 2006a,b). In similar experiments, Morgan (1902) removed all gonads in Schmidtea lugubris, and the animals regenerated to fully functional sexual organisms. It is still possible that the remaining neoblasts in the amputee are only pluripotent and not totipotent, different types of neoblasts being competent for different (groups of) tissues. A convincing experiment to prove the totipotency of neoblasts would be the injection of a single neoblast into a lethally X-irradiated animal that is to be amputated some weeks after the injection. In case the animal survives, and is able to restore all removed organs, then either redifferentiation of cells would have taken place, or (at least some) adult neoblasts would be totipotent. A similar experiment, with the injection of $20,000-24,000$ cells enriched in neoblasts $(30-88 \%$ neoblasts) into X-irradiated $S$. mediterranea, was performed by 
Bagunà et al. (1989). This experiment was not replicated in the literature, but the results made highly probable that neoblasts as a whole are totipotent in routine cell turnover, leaving open the questions if this holds also true for regeneration and if this totipotency applies to one single cell type or to several different types of stem cells.

Are neoblasts in species with limited regeneration potential not totipotent, or are they just not receiving the right stimulus or guidance for regeneration? Supporting the latter notion is the ability of Macrostomum to duplicate heads after longitudinal incision (Fig. 2d and Egger et al. 2006a,b), while decapitated animals were never observed to regenerate a head (Egger et al. 2006a,b). In this species, it seems that stimuli from the brain are required to duplicate or regenerate the brain. Is there a specific subset of predetermined "brain" neoblasts in species that cannot regenerate a brain? These neoblasts could be located in the vicinity of the brain and therefore lost by amputation of the brain. Brain excision experiments in polyclads, where only the encapsuled brain was removed (von Levetzow 1939; Koopowitz et al. 1976), do not support the existence of such brain-specific neoblasts, as these animals were not able to regenerate the brain. Also, amputation experiments in M. lignano, where only brain and the neoblast-free rostrum were amputated, showed no brain regeneration (Egger et al. 2006a,b). While neoblasts are required for regeneration in general, they do not determine whether a species is able to regenerate a specific organ such as the head, as was found with grafting experiments in triclads (Brøndsted 1969).

Can a single neoblast from an adult develop to a whole organism in an adequate environment, just like a zygote? For the parasitic flatworm Taenia crassiceps, it was shown that single cells of trypsinated cysticerci are able to produce complete cysticerci in the mouse host (Toledo et al. 1997). So in these cestodes, a single totipotent cell, other than a zygote, is able to recover a whole animal. No such experiment is known for free-living flatworms. Besides the difficulty in providing a suitable culture medium, distinct differences between a single neoblast and a zygote are yolk content or surrounding yolk cells and maternal determinants that are present in eggs, but not in neoblasts. Do (all or some) neoblasts have embryonic characteristics, as some authors held (e.g., Keller 1894)? When and where do neoblasts origin in the embryo? Polyclads with their clear and traceable embryonic development appear to be suitable flatworms for investigating these questions.

\section{Heteromorphoses}

Hetermorphoses, i.e., the occurrence of supernumerary heads or tails, in species that cannot regenerate an amputated head, have shown that the regeneration potential of neoblasts is not to be equated with the regeneration capacity of the species. Heteromorphoses are also a placative warning sign for the dangers coming with the ability to regenerate (all) organs. Last but not the least, hetermorphoses in free-living flatworms show that the duplication of axes is not only possible during embryonic development (Fig. 2b, siamese twins), but also in adults, even after comparably minor surgery. The $M$. lignano specimen depicted in Fig. 2c,d shows that a longitudinal incision in the anterior part of the animal can establish a second anteroposterior body axis parallel to the original axis. The new anteroposterior axis reaches from the rostrum tip to the caudal tip and duplicates all organs including head, pharynx, female genital opening, and male copulatory organ. Even the breadth of the animal approximates that of two single specimens. Over time, however, the animal degenerated in both halves losing all eyes, and was not able to recover to a viable state (Egger et al. 2006a,b). A decreased viability in animals with heteromorphoses was also observed in Macrostomum appendiculatum and Bothrioplana bohemica (Sekera 1911), as well as in S. leucops (Ruhl 1927b).

In triclads, duplicated or even multiple heads (e.g., 10headed D. lacteum, Lus 1924) and tails have been generated and studied by a great number of researchers (see Brøndsted 1969). Randolph (1897) made longitudinal and lateral incisions in Planaria maculata [today: Dugesia (Girardia) tigrina] leading to additional eyes and pharynges. It was found that when a duplicated head or tail was amputated close enough to the second main axis, regeneration was inhibited by the presence of the remaining head or tail (Rand and Mildred 1926). In the polyclad Leptoplana, double-heads and double-tails were experimentally produced by longitudinal incision (Child 1905a). With the same method, tails, but not heads, could be duplicated in the rhabdocoel Mesostoma (Fulinski 1922) and in the acoel P. caudatus (Keil 1929). Constrastingly, heads, but not tails could be duplicated by incision in the catenulid S. leucops (Ruhl 1927b).

Another type of heteromorphoses is created by provoking a body axis reversed to the original body axis. This was found in M. lignano after longitudinal incision in the head, that induced the creation of a tail plate appendage in the anterior body region (Egger et al. 2006a,b). Agata et al. (2003) suggested that one of the main functions of a blastema in triclads is producing positional signals and inducing intercalary regeneration between stump and blastema. An incision may cause the building of a very small blastema at the wound site, which provides anterior or posterior positional signals. Depending on the signal the blastema produces, either a head or a tail plate is subsequently formed.

Incisions may also have a long-range effect, as was observed by Randolph (1897) in triclads, where outgrowths appeared at body regions not affected by incision. A similar phenomenon as in M. lignano was observed by Steinböck 
(1967) in $H$. giselae, where an animal was divided into 10 pieces, one of which developed a tail-like structure at the anterior end besides the head. Just as was observed in $M$. lignano (Egger et al. 2006a,b), the anterior tail in H. giselae was gradually moving along the side of the animal towards the posterior end, when after 36 days the additional tail was located at the posterior tip of the animal.

\section{Conclusion}

A pronounced regeneration capacity and the existence of possibly totipotent stem cells in adults are two key features of many flatworms not found in this combination in any other bilaterian taxa. It could be shown that regeneration follows similar principles in many different taxa of freeliving flatworms, even if the regeneration capacity can vastly differ. Such comparisons make it possible to recognize unique patterns, and also to form general ideas how, why, and when regeneration works. For this reason, it appears to be valuable to establish several flatworm model organisms from various taxa, to address old and upcoming questions regarding regeneration and the neoblast stem cell system. One of these comparably new model flatworms is M. lignano, a small but versatile worm that facilitates regeneration studies on the cellular and molecular level.

Acknowledgements David Halton and Angela Mousley are to be thanked for the kind gift of a GYIRFamid antibody. Sachiko Ishida and her lab members introduced me to the embryonic development of polyclads. Roland Peter gave clues to literature, and Peter Ladurner alerted me to an interesting animal. Bernd Pelster and Lukas Schärer kindly provided additional equipment. Many thanks to librarians around the world, without whom this work would not have been possible. This work was supported by FWF projects 16618 and 19232.

\section{References}

Åkesson B, Gschwentner R, Hendelberg J, Ladurner P, Müller H, Rieger R (2001) Fission in Convolutriloba longifissura: asexual reproduction in acoelous turbellarians revisited. Acta Zool (Stockh) 82:231-239

Agata K (2003) Regeneration and gene regulation in planarians. Curr Opin Genet Dev 13:492-496

Agata K, Watanabe K (1999) Molecular and cellular aspects of planarian regeneration. Semin Cell Dev Biol 10:377-383

Agata K, Tanaka T, Kobayashi C, Kato K, Saitoh Y (2003) Intercalary regeneration in planarians. Dev Dyn 226:308-316

Ax P, Schulz E (1959) Ungeschlechtliche Fortpflanzung durch Paratomie bei acoelen Turbellarien. Biol Zentralbl 78:613-622

Baguñà J (1998) Planarians. In: Ferretti P, Géraudie J (eds) Cellular and molecular basis of regeneration: from invertebrates to humans. Wiley, pp 135-165

Baguñà J, Riutort M (2004a) Molecular phylogeny of the Platyhelminthes. Can J Zool 82:168-193

Baguñà J, Riutort M (2004b) The dawn of bilaterian animals: the case of acoelomorph flatworms. Bioessays 26:1046-1057
Baguñà J, Saló E, Auladell C (1989) Regeneration and pattern formation in planarians-III. Evidence that neoblasts are totipotent stem cells and the source of blastema cells. Development 107:77-86

Boyer BC (1986) Determinative development in the polyclad turbellarian, Hoploplana inquilina. Int J Invertebr Reprod Dev 9:243-251

Boyer BC (1989) The role of the first quartet micromeres in the development of the polyclad Hoploplana inquilina. Biol Bull 177:338-343

Boyer BC (1992) The effect of deleting opposite first quartet micromeres on the development of the polyclad Hoploplana. Biol Bull 183:374-375

Brøndsted HV (1939) Regeneration in planarians investigated with a new transplantation technique. K Dan Vidensk Selsk Biol Meddr 15:1-39

Brøndsted HV (1942) Further experiments on regeneration - problems in planarians. K Dan Vidensk Selsk Biol Meddr 17:1-27

Brøndsted HV (1969) Planarian regeneration. Pergamon Press, Oxford

Cardona A, Hartenstein V, Romero R (2005) The embryonic development of the triclad Schmidtea polychroa. Dev Genes Evol 215:109-131

Cebrià F, Newmark PA (2005) Planarian homologs of netrin and netrin receptor are required for proper regeneration of the central nervous system and the maintenance of nervous system architecture. Development 132:3691-3703

Cebrià $\mathrm{F}$, Kudome $\mathrm{T}$, Nakazawa $\mathrm{M}$, Mineta $\mathrm{K}$, Ikeo $\mathrm{K}$, Gojobor T, Agata K (2002a) The expression of neural-specific genes reveals the structural and molecular complexity of the planarian central nervous system. Mech Dev 116:199-204

Cebrià F, Kobayashi C, Umesono Y, Nakazawa M, Mineta K, Ikeo K, Gojobori T, Itoh M, Taira M, Sánchez Alvarado A, Agata K (2002b) FGFR-related gene nou-darake restricts brain tissues to the head region of planarians. Nature 419:620-624

Child CM (1903a) Studies on regulation. I. Fission and regulation in Stenostoma. Arch Entwm 15:187-237, 355-420

Child CM (1903b) Studies on regulation. II. Experimental control of form-regulation in zooids and pieces of Stenostoma. Arch Entwm 15:603-637

Child CM (1904a) Studies on regulation. IV. Some experimental modifications of form-regulation in Leptoplana. J Exp Zool 1:95-133

Child CM (1904b) Studies on regulation. V. The relation between the central nervous system and regeneration in Leptoplana: posterior regeneration. J Exp Zool 1:463-512

Child CM (1904c) Studies on regulation. VI. The relation between the central nervous system and regulation in Leptoplana: anterior and lateral regeneration. J Exp Zool 1:513-557

Child CM (1905a) Studies on regulation. VII. Further experiments on form-regulation in Leptoplana. J Exp Zool 2:253-285

Child CM (1905b) Studies on regulation. VIII. Functional regulation and regeneration in Cestoplana. Arch Entwm 19:261-294

Child CM (1905c) Studies on regulation. X. The positions and proportions of parts during regulation in Cestoplana in the absance of the cephalic ganglia. Arch Entwm 20:157-186

Child CM (1907) The localisation of different methods of formregulation in Polychoerus caudatus. Arch Entwm Org 23:227-248

Dalyell JG (1814) Observations on some interesting phenomena in animal physiology exhibited by several species of planariae. Edinburgh

Egger B, Ishida S (2005) Chromosome fission or duplication in Macrostomum lignano (Macrostomorpha, Plathelminthes) remarks on chromosome numbers in "archoophoran turbellarians". J Zool Syst Evol Res 43:127-132

Egger B, Salvenmoser W, Nimeth K, Adamski Z, Ladurner P, Rieger $\mathrm{R}$ (2005) Role and dynamics of stem cells during regeneration in 
the flatworm Macrostomum lignano. Folia Histochem Cytobiol 43 (Suppl 1):40

Egger B, Ladurner P, Nimeth K, Gschwentner R, Rieger R (2006a) The regeneration capacity of the flatworm Macrostomum lignanoon repeated regeneration, rejuvenation, and the minimal size needed for regeneration. Dev Genes Evol 216:565-577

Egger B, Ladurner P, Nimeth K, Gschwentner R, Rieger R (2006b) The regeneration capacity of the flatworm Macrostomum lignanoon repeated regeneration, rejuvenation, and the minimal size needed for regeneration. Dev Genes Evol 216:579-580

Ehlers U (1985) Das phylogenetische System der Plathelminthes. Fischer, Jena

Faisst J, Keenan CL, Loopowitz H (1980) Neuronal repair and avoidance behavior in the flatworm Notoplana acticola. J Neurobiol 11:483496

Fulinski B (1922) Über das Restitutionsvermögen der Rhabdocoelen. Arch Entwm 51:575-586

Ghirardelli E (1965) Differentiation of the germ cell and regeneration of the gonads in planarians. In: Regeneration in animals. Amsterdam, pp 177-184

Giesa S (1966) Die Embryonalentwicklung von Monocelis fusca Oersted. Z Morphol Ökol Tiere 57:137-230

Goss RJ (1991) The natural history (and mystery) of regeneration. In: Dinsmore CE (ed) A history of regeneration research: milestones in the evolution of science. Cambridge University Press, Cambridge

Gremigni V (1992) Features of sex evolution in PlatyhelminthesTurbellaria. In: Dallai R (ed) Sex origin and evolution. Selected symposia and monographs U Z I, vol 6. Mucchi, Modena, pp. 69-86

Hagleithner G (1946) Das Regenerations problem bei Turbellarien. Dissertation, Innsbruck

Hanson ED (1967) Regeneration in acoelous flatworms: the role of the peripheral parenchyma. Roux’ Arch Entwm 159:298-313

Haranghy L, Balázs A (1964) Ageing and rejuvenation in planarians. Exp Gerontol 1:77-91

Hein C (1928) Zur Kenntnis der Regnerationsvorgänge bei den Rhabdocoelen. Mit Angaben über den feineren Bau und die Lebensäußerungen. Z Wiss Zool 130:469-546

Hendelberg J, Åkesson B (1988) Convolutriloba retrogemma gen. et sp.n., a turbellarian (Acoela, Platyhelminthes) with reversed polarity of reproductive buds. Fortschr Zool 36:321-327

Hendelberg J, Åkesson B (1991) Studies of the budding process in Convolutriloba retrogemma (Acoela, Platyhelminthes). Hydrobiologia 227:11-17

Henley C (1974) Platyhelminthes (Turbellaria). In: Giese AC, Pearse JS (eds) Reproduction of marine invertebrates, vol 1. Acoelomate and pseudocoelomate metazoans. Academic, New York, pp 267-343

Hyman LH (1951) The Invertebrates. II. Platyhelminthes and Rhynchocoela. The acoelomate Bilateria. McGraw-Hill, New York

Ishida S (1998) Regeneration in the polyclads. In: Teshirogi W, Watanabe K (eds) Morpho-differentiation in planarians. Kyoritsu Shuppan Company, Tokyo, pp 223-240

Jondelius U (2004) Cleavage in Nemertoderma westbladi (Nemertodermatida) and its phylogenetic significance. Zoomorphology 123:221-225

Keil EM (1929) Regeneration in Polychoerus caudatus Mark. Biol Bull 57:225-244

Keller J (1894) Die ungeschlechtliche Fortpflanzung der Süßwasserturbellarien. Jena Z Med Naturwiss 28:370-407

Koinuma S, Umesono Y, Watanabe K, Agata K (2003) The expression of planarian brain factor homologs, DjFoxG and DjFoxD. Gene Exp Pat 3:21-27

Koopowitz H, Silver D, Rose G (1975) Neuronal plasticity and recovery of function in a polyclad flatworm. Nature 256:737-738
Koopowitz H, Silver D, Rose G (1976) Primitive nervous systems. Control and recovery of feeding behavior in the polyclad flatworm, Notoplana acticola. Biol Bull 150:411-425

Kreshchenko N, Sheiman I, Reuter M, Gustafsson MKS, Halton DW, Maule AG (2001) Effects of FMRFamide-related peptides and neuropeptides $\mathrm{F}$ on planarian regeneration (Platyhelminhtes, Tricladida). Belg J Zool 131:147-148

Ladurner P, Mair GR, Reiter D, Salvenmoser W, Rieger RM (1997) Serotonergic nervous system of two macrostomid species: recent or ancient divergence? Invertebr Biol 116:178-191

Ladurner P, Rieger R, Baguñà J (2000) Spatial distribution and differentiation potential of stem cells in hatchlings and adults in the marine platyhelminth Macrostomum sp.: a bromodeoxyuridine analysis. Dev Biol 226:231-241

Le Moigne A (1966) Etude du développement embryonnaire et recherches sur les cellules de régénération chez l'embryon de la Planaire Polycelis nigra (Turbellarié, Triclade). J Embryol Exp Morphol 15:39-60

Lender TH (1950) Démonstration du role organisateur du cerveau dans la régénération des yeux de la planaire Polycelis nigra par la méthode des greffes. C R Soc Biol 144:1407

Lender TH (1951a) Découverte d'une plainaire américaine, Dugesia (Euplanaria) tigrina. Girard Ass Philom d'Alsace et de Lorraine 9:51

Lender TH (1951b) Sur les propriétés et l'étendue du champ d'organisation du cervau dans la régénération des yeux de la planaire Polycelis nigra. C r Séanc Soc Biol 145:1211

Lender TH (1951c) Sur les capacités inductrices de l'organisateur des yeux dans la régénération de la planaire Polycelis nigra (Ehr.): action du cerveau en voie de dégénérescence et en greffes hétéroplastiques. C r Séanc Soc Biol 145:1378

Lus J (1924) Studies on regeneration and transplantation in Turbellaria. I. Some considerations on polarity and heteromorphosis in fresh water planarians. Bull Soc Nat Mosc Sect Biol, Exp 1

Monti R (1900a) La rigenerazione nelle planarie marine. Mem R Ist Lomb 19:1-16

Monti R (1900b) Studi sperimentali sulla rigenerazione nei Rhabdoceli marini (Plagiostoma girardii-Graff). Rend Ist Lomb Sci Lett Ser II 33:915-917

Moraczewski J (1977) Asexual reproduction and regeneration of Catenula (Turbellaria, Archoophora). Zoomorphologie 88:65-80

Morgan TH (1902) Growth and regeneration in Planaria lugubris. Arch Entwm 13:179-212

Morgan LV (1905) Incomplete anterior regeneration in the absence of the brain in Leptoplana littoralis. Biol Bull 9:187-193

Morris J, Nallur R, Ladurner P, Egger B, Rieger R, Hartenstein V (2004) The embryonic development of the flatworm Macrostomum sp. Dev Genes Evol 214:220-239

Newmark PA, Sánchez Alvarado A (2001) Regeneration in planaria. Encyclopedia of Life Sciences, Nature Publishing Group, London, 1-7

Newmark PA, Sánchez Alvarado A (2002) Not your father's planarian: a classic model enters the era of functional genomics. Nat Rev Genet 3:210-220

Nimeth KT, Mahlknecht M, Mezzanato A, Peter R, Rieger R, Ladurner P (2004) Stem cell dynamics during growth, feeding, and starvation in the basal flatworm Macrostomum sp. (Platyhelminthes). Dev Dyn 230:91-99

Olmsted JMD (1922a) The role of the nervous system in the regeneration of polyclad Turbellaria. J Exp Zool 36:48-56

Olmsted JMD (1922b) The role of the nervous system in the locomotion of certain marine polyclads. J Exp Zool 36:57-66

Pallas PS (1774) Spicilegia zoologica quibus novae imprimis et obscurae animaliu. speciosiconibus atque conamentariis illustratur. Fasc X, Berolini 
Palmberg I (1986) Cell migration and differentiation during wound healing and regeneration in Microstomum lineare (Turbellaria). Hydrobiologia 132:181-188

Palmberg I (1990) Stem cells in microturbellarians - an autoradiographic and immunocytochemical study. Protoplasma 158:109-120

Palmberg I (1991) Differentiation during asexual reproduction and regeneration in a microturbellarian. Hydrobiologia 227:1-10

Pechlaner R (1957) Die Regenerationsfähigkeit von Otomesostoma auditivum (Forel et Duplessis) (Turbellaria). Arch Entwm 150:104-114

Peebles F (1913) Regeneration acoeler Plattwürmer. I. Aphanostoma diversicolor. Bull Inst Océanogr 263:1-5

Peter R, Ladurner P, Rieger RM (2001) The role of stem cell strategies in coping with environmental stress and choosing between alternative reproductive modes: turbellaria rely on a single cell type to maintain individual life and propagate species. Mar Ecol 22:35-51

Pfister D, Ladurner P (2005) The totipotent stem cell system as a source for germ line cells during development and regeneration in the flatworm Macrostomum lignano. Dev Biol 283: 643

Ramachandra NB, Gates RD, Ladurner P, Jacobs DK, Hartenstein V (2002) Embryonic development in the primitive bilaterian Neochildia fusca: normal morphogenesis and isolation of POU genes Brn-1 and Brn-3. Dev Genes Evol 212:55-69

Randolph H (1897) Observations and experiments on regeneration in planarians. Arch Entwm 5:352-3725

Rand HW, Mildred E (1926) Inhibition of regeneration in two-headed or two-tailed planarians. Proc Natl Acad Sci 12:570-574

Reddien PW, Sánchez Alvarado A (2004) Fundamentals of planarian regeneration. Annu Rev Cell Dev Biol 20:725-757

Reddien PW, Bermange AL, Murfitt KJ, Jennings JR, Sánchez Alvarado A (2005) Identification of genes needed for regeneration, stem cell function, and tissue homeostasis by systematic gene perturbation in planaria. Dev Cell 8:635-649

Reuter M, Kreshchenko N (2004) Flatworm asexual multiplication implicates stem cells and regeneration. Can J Zool 82:334-356

Reuter M, Raikova OI, Jondelius U, Gustafsson MKS, Maule AG, Halton DW (2001) Organisation of the nervous system in the Acoela: an immunocytochemical study. Tissue Cell 33:119-128

Rieger R (1986) Asexual reproduction and the turbellarian archetype. Hydrobiologia 132:35-45

Rieger R (1996) Plathelminthes, Plattwürmer. In: Westheide W, Rieger R (eds) Spezielle Zoologie I. Einzeller und Wirbellose Tiere. Gustav Fischer Verlag, Stuttgart, pp 210-258

Rieger RM, Legniti A, Ladurner P, Reiter D, Asch E, Salvenmoser W, Schürmann W, Peter R (1999) Ultrastructure of neoblasts in microturbellaria: significance for understanding stem cells in free-living Platyhelminthes. Invertebr Reprod Dev 35:127-140

Ritter WE, Congdon EM (1900) On the inhibition by artificial section of the normal fission plane in Stenostoma. Proc Calif Acad Sci $3(2): 365-377$

Ruhl L (1927a) Regenerationserscheinungen an Rhabdocoelen. Zool Anz 72:160-175

Ruhl L (1927b) Doppelbildungen und andere Mißbildungen bei Stenostomum. Zool Anz 72:180-190

Saló E (2006) The power of regeneration and the stem-cell kingdom: freshwater planarians (Platyhelminthes). Bioessays 28:546-559

Saló E, Baguñà J (2002) Regeneration in planarians and other worms: new findings, new tools, and new perspectives. J Exp Zool 292:528-539

Salvenmoser W, Riedl D, Ladurner P, Rieger R (2001) Early steps in the regeneration of the musculature in Macrostomum sp. (Macrostomorpha). Belg J Zool 131 (Suppl 1):105-109

Sánchez Alvarado A (2000) Regeneration in the metazoans: why does it happen? Bioessays 22:578-590
Sánchez Alvarado A (2003) The freshwater planarian Schmidtea mediterranea: embryogenesis, stem cells and regeneration. Curr Opin Genet Dev 13:438-444

Sánchez Alvarado A (2004) Regeneration and the need for simpler model organisms. Phil Trans R Soc Lond B 359:759-763

Sánchez Alvarado A (2006) Planarian regeneration: its end is its beginning. Cell 124:241-245

Sánchez Alvarado A, Kang H (2005) Multicellularity, stem cells, and the neoblasts of the planarian Schmidtea mediterranea. Exp Cell Res 306:299-308

Scharer L, Joss G, Sandner P (2004) Mating behaviour of the marine turbellarian Macrostomum sp.: these worms suck. Mar Biol $145: 373-380$

Schultz E (1901) Über Regeneration bei Polycladen. Zool Anz 24:527-529

Schultz E (1902) Aus dem Gebiete der Regeneration. II. Über die Regeneration der Turbellarien. Z Wiss Zool 72:1-30

Seilern-Aspang F (1958) Entwicklungsgeschichtliche Studien an paludicolen Tricladen. Arch Entwm 150:425-480

Sekera E (1911) Weitere Beiträge zu den Doppelbildungen bei den Turbellarien. Ber Ges Wiss Prag Math-naturwiss K1 III:1-7

Shibata N, Umesono Y, Orii H, Sakurai T, Watanabe K, Agata K (1999) Expression of vasa(vas)-related genes in germline cells and totipotent somatic stem cells in planarians. Dev Biol 206:73-87

Sivickis PB (1930) A quantitative study of regeneration along the main axis of the triclad body. Arch Zool Ital 16:430-449

Smith JPS, Tyler S, Rieger RM (1986) Is the Turbellaria polyphyletic? Hydrobiologia 132:13-21

Steinböck O (1927) Monographie der Prorhynchidae (Turbellaria). Z Morphol Ökol Tiere 8:538-662

Steinböck O (1954) Sobre la misión del "plasmodio digestivo" en la regeneracion de Amphiscolops (Turbellaria acoela). Publ Inst Biol Apl (Barcelona) 17:101-117

Steinböck O (1955) Regeneration azöler Turbellarien. Zool Anz (Suppl Bd) 18:86-94

Steinböck O (1963a) Regenerations- und Konplantationsversuche an Amphiscolops sp. (Turbellaria acoela). Arch Entwm Org 154:308-353

Steinböck O (1963b) Regeneration experiments and phylogeny. Comp Biol Phylog 8:108-112

Steinböck O (1966) Die Hofsteniiden (Turbellaria acoela): Grundsätzliches zur Evolution der Turbellarien. Z Zoolog Syst Evolforsch 4:58-195

Steinböck O (1967) Regenerationsversuche mit Hofstenia giselae Steinb. (Turbellaria Acoela). Arch Entwm 158:394-458

Steinmann P, Bresslau E (1913) Die Strudelwürmer (Turbellaria). In: Ziegler HE, Woltereck R (eds) Monographien einheimischer Tiere, Band 5. Klinkhardt Verlag, Leipzig

Stevens NM, Boring AM (1905) Regeneration in Polychoerus caudatus. J Exp Zool 2:335-346

Teshirogi W, Ishida S, Yamazaki H (1977) Regenerative capacities of transverse pieces in the two species of freshwater planarian, Dendrocoelopsis lactea and Polycelis sapporo. Sci Rep Hirosaki Univ 24:55-72

Toledo A, Cruz C, Fragoso G, Laclette JP, Merchant MT, Hernandez M, Sciutto E (1997) In vitro culture of Taenia crassiceps larval cells and cyst regeneration after injection into mice. J Parasitol 83:189-193

Török LJ (1958) Experimental contributions to the regenerative capacity of Dugesia (= Euplanaria) lugubris, O Schm. Acta Biol 9:79

Tyler S, Hooge M (2004) Comparative morphology of the body wall in flatworms (Platyhelminthes). Can J Zool 82:194-210

Tyler S, Schilling S, Hooge M, Bush LF (comp) (2006) Turbellarian taxonomic database. Version $1.5 \mathrm{http}: / / \mathrm{www}$.turbellaria.umaine.edu/ 
van Cleave CD (1929) An experimental study of fission and reconstitution in Stenostomum. Physiol Zool 2:18-58

von Graff L (1882) Monographie der Turbellarien. I. Rhabdocoelida. Leipzig

von Graff L (1908) Acoela und Rhabdoelida. In: Bronn HG (ed) Klassen und Ordnungen des Tierreichs. Vierter Band: Vermes. I. c. Turbellaria. Akad Verl-Ges Geest u Portig, Leipzig

von Levetzow KG (1939) Die Regeneration der polycladen Turbellarien. Arch Entwm 139:780-818

Vannini E (1965) Regeneration and sex gradient in some hermaphroditic animals. In: Regeneration in animals. Amsterdam, pp $160-176$

Vannini E (1966) Alcune aspette attuali dei probleme della rigenerazione. Arch Zool Ital 51:951-958
Wolff E, Lender TH (1950a) Sur le déterminisme de la régénération des yeux chez une planaire d'eau douce Polycelis nigra. $\mathrm{C} \mathrm{r}$ Séanc Soc Biol 144:1213

Wolff E, Lender TH (1950b) Sur le role organisateur du cerveau dans la régénération des yeux chez une planaire d'eau douce. $\mathrm{C} r$ Acad Sci 230:2238-2239

Yamasu T (1991) Fine structure and function of ocelli and sagittocysts of acoel flatworms. Hydrobiologia 227:273-282

Younossi-Hartenstein A, Hartenstein V (2000) The embryonic development of the polyclad flatworm Imogine mcgrathi. Dev Genes Evol 210:383-398

Younossi-Hartenstein A, Hartenstein V (2001) The embryonic development of the temnocephalid flatworms Craspedella pedum and Diceratocephala boschmai. Cell Tissue Res 304:295-310 